\title{
EPIDEMIOLOGICAL ASSESSMENT OF DYMAMICS OF THE PREVALENCE AND INCIDENCE OF THE THYROID GLAND DISEASES IN UKRAINE AND CHERNIVTSI REGION
}

\author{
I.I. Kamyshna ${ }^{1}$, L.B. Pavlovich', V.A. Maslyanko ${ }^{2}$, Zh.A. Chornenka ${ }^{2}$
}

${ }^{1}$-Тернопільській національний медичний університет ім. І.Я. Горбачевського, м.Тернопіль, Україна

${ }^{2}$-Буковинський державний медичний університет, м. Чернівці, Україна

Objective - to assess the dynamics of the prevalence and incidence of the thyroid disease among the adult population of Ukraine and Chernivtsi region during 2015-2020.

Material and methods. A comparative analysis of official accounting and reporting statistics of the Ministry of Health of Ukraine and the main indicators of the endocrinology service of Chernivtsi region on the prevalence and incidence of adult pathology of the thyroid gland over the past 5 years.

Results. In Ukraine, the number of pathologies of the thyroid gland has increased, accounting for $48 \%$ of the total incidence of endocrine diseases. The most common pathology is diffuse and nodular goitres. Their level in the western region, including Chernivtsi region, is higher than the national average. In Ukraine the incidence of hypothyroidism has increased $20.3 \%$ for 5 years. Thyrotoxicosis increased $9.1 \%$, and the prevalence of thyroiditis increased $16.8 \%$. The increase in the Chernivtsi region was slightly lower. The high frequency of thyroid pathologies depends on the imbalance of trace elements and vitamins in the diet against a background of iodine deficiency in the diet, environmental degradation and insufficient preventive measures.

Conclusions. The analysis shows that in the western regions of Ukraine it is necessary to apply a differentiated approach to the diagnosis, treatment and prevention of patients with various thyroid diseases.

\section{ЕПІДЕМІОЛОГІЧНА ОЦІКАА ДИНАМІКИ РОЗПОВСЮДЖЕНОСТІ ТА ЗАХВОРЮВАНОСТІ ЩИТОПОДІБНОЇ ЗАЛОЗИ В УКРАЇНІ ТА ЧЕРНІВЕЦЫКІЙ ОБЛАСТІ}

\section{І.І. Камична, Л.Б. Павлович, В.А. Маслянко, Ж.А. Чорненька}

Мета дослідження - оцінити динаміку поширеності та стан захворюваності щзитоподібної залози серед дорослого населення Украӥни та Чернівецької області протягом 2015-2020 pp.

Матеріали і методи. Проведено порівняльний аналіз офіційних обліковозвітних статистичних даних МОЗ Украӥни та основних показників діяльності ендокринологічної служби Чернівецької області стосовно поширеності та захворюваності дорослого населення на патологію ЩЗ за останні 5 років.

Результати. В Украйні збільшилася кількість патологій щчитовидної залози, щчо становить 48\% від загальної захворюваності на ендокринні захворювання. Найбільш поширеною патологією є дифузний та вузловий зоб. Їх рівень у західному регіоні, у тому числі й Чернівецькій області, вищий за середній показник по краӥні. За 5 років захворюваність по Україні на гіпотиреоз зросла на 20,3\%. Тиреотоксикоз збільшився на 9,1\%, а поширеність тиреоїдту зросла на 16,8\%. Дещяо нижчим був приріст по Чернівецькій області. Висока частота патологій щчитовидної залози залежить від дисбалансу мікроелементів та вітамінів на тлі нестачі йоду в раціоні населення, погіршення стану навколишнього середовища та недостатніх профілактичних заходів.

Висновки. Аналіз показує, щзо в західних регіонах Украӥни необхідно застосовувати диферениійований підхід до діагностики, лікування та профілактики різних захворювань щитовидної залози.

\section{ЭПИДЕМИОЛОИЧЕСКАЯ ОЦЕНКА ДИНАМИКИ РАСПРОСТРАНЕННОСТИ И ЗАБОЛЕВАЕМОСТИ ЩИТОВИДНОЙ ЖЕЛЕЗЫ В УКРАИНЕ И ЧЕРНОВИЦКОЙ ОБЛАСТИ}

И.И. Камишна, Л.Б. Павлович, В.А. Маслянко, Ж.А. Чорненькая

Цель исследования - оценить динамику распространенности и состояние заболеваемости щитовидной железы среди взрослого населения Украинь и
Key words: thyroid gland, morbidity, prevalence, dynamics.

Clinical and experimental pathology 2021. Vol.20, № 3 (77). P. 75 - 81 .

DOI:10.24061/1727-4338. XX.3.77.2021.11

E-mail: iryna.bilous2017@gmail. com
Ключові слова: щуитоподібна залоза, захворюваність, поширеність, динаміка.

Клиническая и экспериментальная патология 2021. T.20, №3 (77). C. $75-81$.

\section{Ключевые слова:} щуитовидная железа, заболеваемость, распространенность, динамика

Клінічна та експериментальна патологія 2021. T.20, №3 (77). C. 75 - 81. 
Черновицкой области в течение 2015-2020 г2.

Материалы и методы. Проведен сравнительный анализ официальных учетноотчетных статистических данных Минздрава Украины и основных показателей деятельности эндокринологической службы Черновицкой области в отнотении распространенности и заболеваемости взрослого населения на патологию изитовидной железы за последние 5 лет.

Результаты. В Украине увеличилось количество патологий щчитовидной железы, что составляет 48\% от общей заболеваемости эндокринными заболеваниями. Наиболее распространенной патологией является диффузный и узловой зоб. Их уровень в западном регионе, в том числе и Черновицкой области, выме среднего показателя по стране. За 5 лет заболеваемость по Украине гипотиреозом выросла на 20,3\%. Тиреотоксикоз увеличился на 9,1\%, а распространенность тиреоидита выросла на 16,8\%. Несколько ниже был прирост по Черновицкой области. Высокая частота патологий щитовидной железы зависит от дисбаланса микроэлементов и витаминов на фоне недостатка йода в рационе населения, ухудшения состояния окружающей среды и недостаточных профилактических мероприятий.

Выводы. Анализ показывает, что в западных регионах Украины необходимо применять дифференциированный подход к диагностике, лечению и профилактике различных заболеваний щзитовидной железы.

\section{Introduction}

One of the priority tendencies of health care in most countries is the prevention of iodine deficiency diseases (IDD), i.e. all pathological conditions that develop in the population as a result of iodine deficiency (ID), which can be prevented with normal iodine intake. Pathology of the thyroid gland is one of the most common reasons for the population to seek medical attention, due to its high prevalence in iodine-deficient and contaminated areas, as well as the availability of the research methods. Iodine is necessary for the production of adequate amounts of the thyroid hormones. The daily requirement of iodine depends on age and physiological condition and ranges from 90 to $250 \mu \mathrm{g} /$ day $[1,2]$. Insufficient intake of iodine in the body leads to the development of a chain of sequential adaptive processes aimed at maintaining the normal synthesis and secretion of thyroid hormones. If ID persists for a long time, breakdown of adaptation mechanisms with the subsequent development of IDD occurs.

According to the WHO, about 2 billion people live under conditions of chronic ID, which leads to dramatic consequences: the development of thyroid diseases such as endemic diffuse and nodular goiter, mental and physical retardation of children, cretinism, miscarriage [3]; a significant increase in the risk of radiation-induced thyroid cancer in the event of a nuclear accident. Every year, more than two million adults and 650,000 children with thyroid disease need specialized endocrinological care [4]. It has been proved that in addition to goiter, iodine deficiency has another negative impact on human health. According to WHO experts, iodine deficiency is one of the most common causes of mental retardation. In recent years, studies all round the world have shown that the average level of intellectual development (IQ) in areas with severe iodine deficiency is $15-20 \%$ lower than in areas with iodine deficiency. Iodine deficiency is especially dangerous in childhood, because thyroid hormones are needed to regulate the differentiation of tissues of all organs and systems, including the brain. Depending on the degree of iodine deficiency, there may be a slow psychomotor development up to endemic cretinism.

The medical and social significance and urgency of the problem of IDD in Ukraine is caused by the fact that in almost all regions there is a natural deficiency of iodine. Traditionally in Ukraine, the regions with severe iodine deficiency include Zakarpattia, Ivano-Frankivsk, Volyn, Lviv, Rivne, Chernivtsi and Ternopil regions. One of the most endemic regions of Ukraine in terms of goiter is Chernivtsi, so Bukovyna has various degrees of iodine deficiency. In 1930s and 1970s, the use of iodized salt, antistrumin, and active surgical strategies made significant progress in combating endemic goiter in Bukovina, but in the late 1980s there was a recurrence of endemic goiter due to the cessation of iodine prophylaxis. In addition, over the past ten years, the population's ability to provide itself with sufficient iodine-containing foods has declined sharply, leading to an increase in goiter, an unfavorable trend in thyroid pathology and a significant type II goiter increase among children.

Interest increase to the problems of thyroid pathology in Ukraine in recent years is caused by its growing prevalence among the adult population, the high frequency of temporary and permanent disability $[5,6]$. The leading diseases are thyroid diseases, the absolute number of cases of thyroid diseases in Ukraine over the past 10 years has increased from 689 thousand to 1 million 846 thousand, in terms of prevalence, respectively, 941.6 and 4210.4 cases per 100 thousand population.

\section{Aim of the study}

To assess the state and dynamics of the thyroid diseases prevalence in the adult population of Ukraine and Chernivtsi region on the basis of a comprehensive study of the health of the population.

\section{Material and methods}

A comparative analysis of official accounting and reporting statistics of the Ministry of Health of Ukraine (data from annual reports according to the form № 12 "Report on the number of registered diseases in the area of medical care") and the main indicators of the endocrinology service [7] of the Chernivtsi region

Клінічна та експериментальна патологія. 2021. Т.20, № 3 (77) 
concerning the prevalence and incidence of thyroid pathology in adults for the last 5 years $(2015-2020)$ has been carried out.

\section{Research results and their discussion}

In the structure of thyroid diseases, which are included in official statistics, there are goitres, nodular goitre, thyrotoxicosis, hypothyroidism, thyroiditis [8]. Assessing the prevalence of the thyroid pathology in Ukraine as a whole, it should be noted that from 2015 to 2020 the volume of the thyroid pathology not only increased in general, but its structure also changed $[9,10]$. Thyroid pathology as of 2020 accounts for $48 \%$ of the total endocrinological morbidity, taking into account the fact that thyroid diseases include diffuse goitre I-III degrees, nodular goitre, hypothyroidism, thyroiditis, thyrotoxicosis and cancer of this gland. Diabetes mellitus accounts for approximately $40.0 \%$ of the total structure of endocrine diseases (Fig. 1). Comparing the relevant data for Chernivtsi region, it is impossible not to note

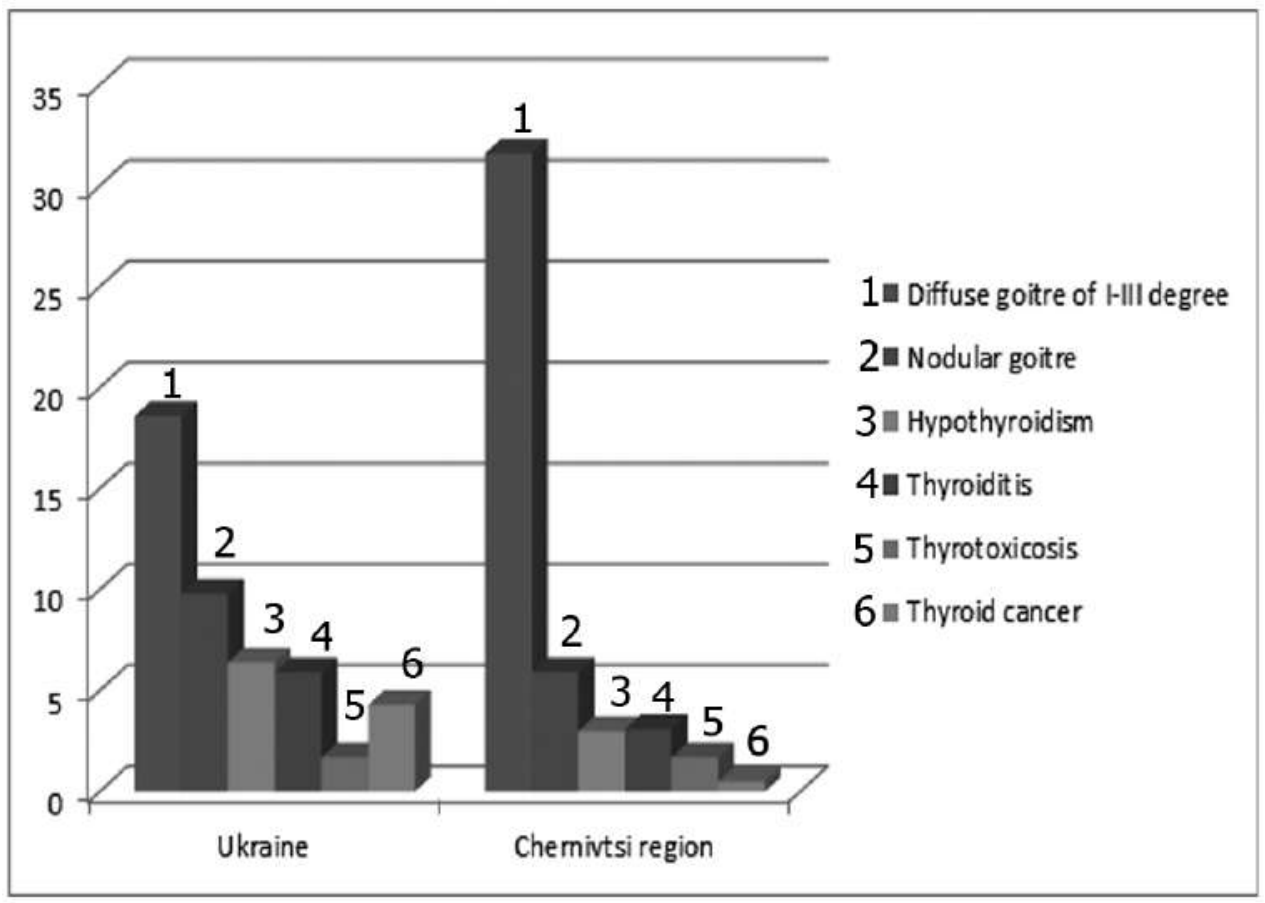

Fig.1 Comparative characteristics of the structure of thyroid diseases in Ukraine and Chernivtsi region.

the significant advantage of diffuse goitre 1.7 times more than all-Ukrainian indices, that certainly emphasizes the endemicity of the region, but it is also positive that thyroid cancer in Chernivtsi region occurs 8.6 times less, in comparison with the corresponding data on Ukraine.

The prevalence of the thyroid pathology among residents of different regions of Ukraine has some differences. The growth of the diseases such as nodular goitre, thyroiditis, thyrotoxicosis has been regularly registered since 2015, and the proportion of hypothyroidism increased in 6.3 times (Table 1). Regarding the prevalence of thyroid diseases among the population of Chernivtsi region, there is a clear increase in all thyroid pathologies (positive dynamics from + $0.4 \%$ for thyroid cancer to $+27.9 \%$ for diffuse goitre from 2015 to 2020 ).

Table 1

Prevalence of thyroid diseases among the adult population of Ukraine and Chernivtsi region in 2015 and 2020 (per 100 thousand population)

\begin{tabular}{|c|c|c|c|c|}
\hline \multirow{2}{*}{ Diseases } & \multicolumn{2}{|c|}{ Ukraine } & 2015 & 2020 \\
\cline { 2 - 5 } & 2015 & 2020 & 3005,7 & 3033,6 \\
\hline $\begin{array}{c}\text { Diffuse goitre of } \\
\text { I-III degree }\end{array}$ & 1731,4 & 1687,9 & 563,8 & 569,1 \\
\hline Nodular goitre & 766,4 & 891,5 & 255,9 & 258,3 \\
\hline Hypothyroidism & 251,6 & 302,8 & 299,7 & 302,5 \\
\hline Thyroiditis & 465,3 & 543,7 & 161,2 & 162,7 \\
\hline Thyrotoxicosis & 144,9 & 158,1 & 47,8 & 48,2 \\
\hline Thyroid cancer & 106,7 & 132,2 & & \\
\hline
\end{tabular}


The most common thyroid pathologies today are diffuse and nodular goitres. The number of registered goitre patients in Ukraine is estimated at hundreds of thousands of patients. The main cause of goitre, as noted earlier, is iodine deficiency in the diet, direct or indirect effects of various negative, including environmental, factors [10]. It is the imbalance of microelement and vitamin composition of diets against a background of deteriorating environmental situation and insufficiently effective preventive measures at the state level that determines the development of thyroid diseases.

Thyroid pathology is observed in different regions of Ukraine with a frequency that sometimes varies dozens of times. The western region of Ukraine, which includes Chernivtsi region, is represented by different climatic and geographical zones (mountains, foothills, plains) and is characterized by a significant prevalence of endemic goitres among the local population.

Estimating the total number of the registered patients with goitre, there is a tendency to reduce the prevalence of goitre of the first degree. The number of new cases in 2015 was 48,649, and in 2020 - 34,861. Over the past 5 years, goitre of II-III degrees also tended to decrease slightly, so in 2015 the prevalence was 156,613 cases, and in 2020 - 153,556 cases, which per 31 thousand of the population constitutes 31.5 and 28.6 new cases. Today Chernivtsi region ranks seventh in the prevalence (27,352 cases) of diffuse goitre of I-III degree, being inferior only to the Transcarpathian, Volyn, IvanoFrankivsk, Ternopil and Vinnytsia regions, compared to 2015, where the Chernivtsi region ranks second place after the Transcarpathian region. These data really reflect the positive dynamics of the prevention work and educational and informational awareness of the population in Ukraine on the reduction of thyroid disease. We would like to emphasize once again that the level of prevalence and morbidity in most regions of the western parts of Ukraine is higher than the national average and the indices of the north-eastern regions. This is due to the much higher incidence of thyroid pathology in the population of the western regions and as a consequence of the endemicity of iodine deficiency in these regions.

Nodular goitre is one of the forms of this pathology, which causes constant clinical interest due to the threat of malignancy of these tumours. The dynamics of epidemiological observations on the prevalence of nodular goitre in the country and Chernivtsi region is characterized by an increase in the prevalence and incidence of nodular goitre over the past five years (Fig. 2). Thus, if in 2016 in Ukraine the prevalence of pathology was 707.8 per 100 thousand population, then after 5 years the figure slowly increased to 891.5 cases, respectively $(+25.9 \%)$. The situation with the prevalence of nodular goitre in Chernivtsi region was slightly different - the peak fell in 2019 - 640.8 per 100 thousand of the population, with a positive increase $16.6 \%$ from 2015 to 2019 , and negative $11,2 \%$ in 2020 in terms of visibility.

The existing high indices of newly diagnosed patients with nodular goitre in the country (Fig. 3) in 2016 were 71.9 , and at the end of 2020 - 90.2 initially established cases per 100 thousand population, with

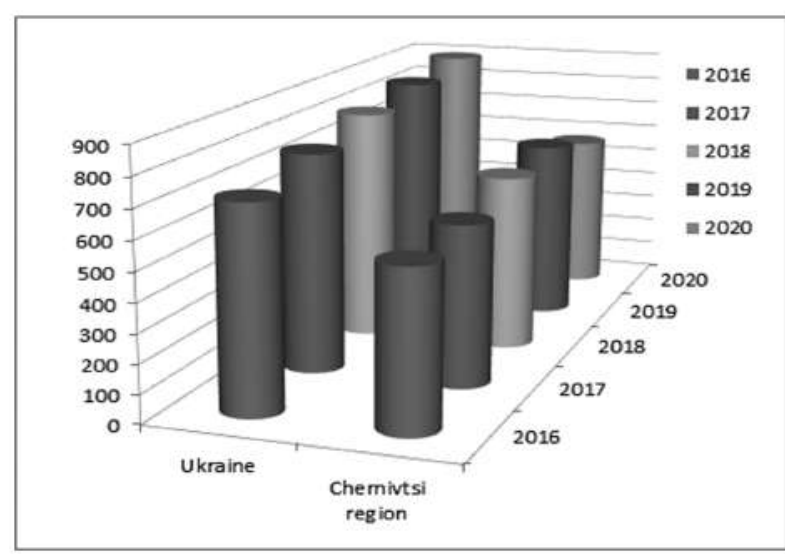

Fig.2 Dynamics of prevalence of nodular goitre in Ukraine and Chernivtsi region (per 100 thousand population).

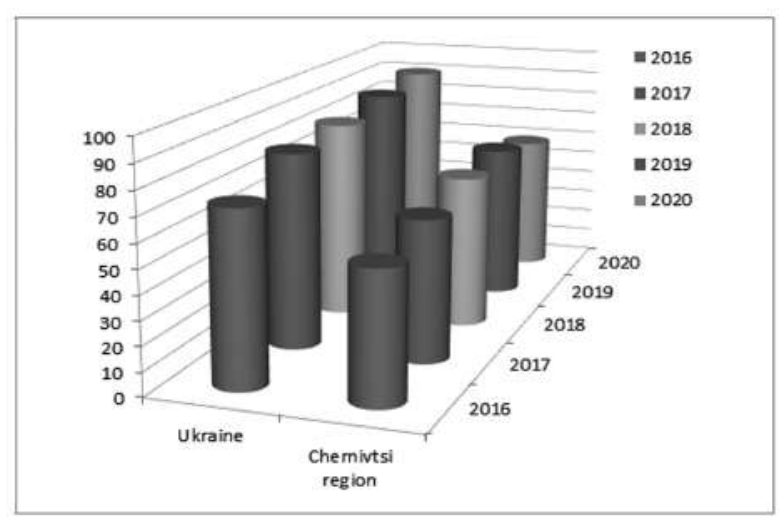

Fig. 3. Dynamics of nodular goitres in Ukraine and Chernivtsi region (per 100 thousand population).

a positive increase of $+25.5 \%$ in terms of clarity. In Chernivtsi region, a similar situation was observed as to the incidence of nodular goitre by 2019 (peak incidence 65.7 per 100 thousand population) and a positive increase of $+21.4 \%$ and a decrease in 2020 (59.2 per 100 thousand population) and a negative increase $-9.8 \%$ in visibility.

Diagnosis of nodular goitres has significantly improved in recent years due to the modern ultrasound examinations, which indicates an overall increase in the disease.

Compared with other pathologies, thyrotoxicosis is observed much less frequently, but the number of cases is also measured in tens of thousands of patients. The prevalence of thyrotoxicosis in Ukraine in 2015 (Fig. 4) was 155.2, in Chernivtsi region - 197.3 per 100 thousand population; the incidence for Ukraine was 13.8 cases, for Chernivtsi region - 14.3 per 100 thousand population, which almost two times prevailed over even the allUkrainian figures. In 2020, the prevalence for Ukraine was 168.1, for Chernivtsi region - 217.6 (1.5 times higher than all-Ukrainian) per 100 thousand population; the incidence was diagnosed in 16.4 cases for Ukraine and 11.7 per 100 thousand population for Chernivtsi region.

Thus, for 5 years the increase in prevalence for Ukraine was about $+8 \%$, for Chernivtsi region - $+10.3 \%$; morbidity: $+18.8 \%$ for Ukraine, but for the Chernivtsi region slightly decreased $-18.2 \%$.

Клінічна та експериментальна патологія. 2021. Т.20, № 3 (77) 


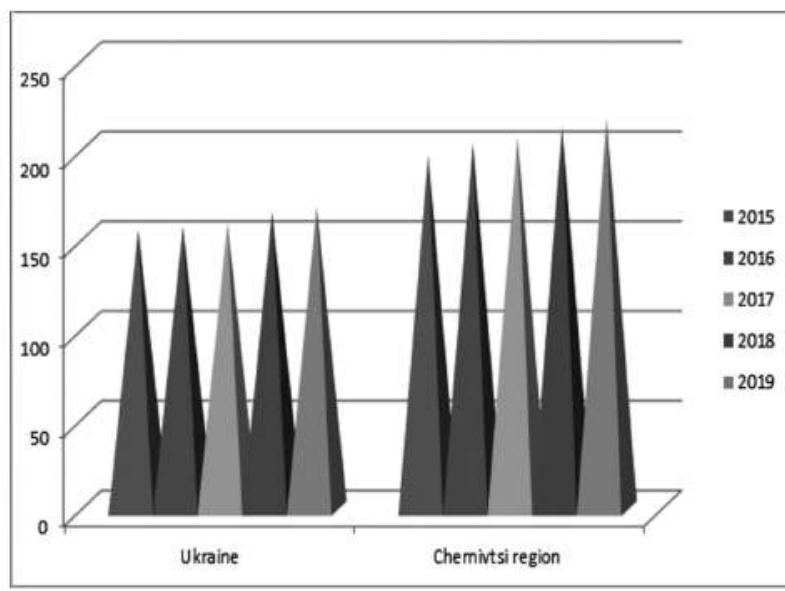

Fig.4. Dynamics of prevalence of thyrotoxicosis in Ukraine and Chernivtsi region (per 100 thousand population).

Having analysed the levels of primary incidence and prevalence of thyroid cancer (Fig. 5) in Ukraine and Chernivtsi region from 2015 to 2020, a clear upward trend was established. Thus, if in 2015 the prevalence of this pathology for Ukraine was 90.1 cases per 100 thousand of the population, then by the end of 2020 its level increased to 132.2 per 100 thousand population (i.e. $46.7 \%$ in terms of clarity). For the Chernivtsi region for 5 years, the increase in the prevalence of thyroid cancer constituted $+29.2 \%$, i.e. from 48.4 in 2015 to 62.4 in 2020 cases per 100 thousand of the population for 5 years.

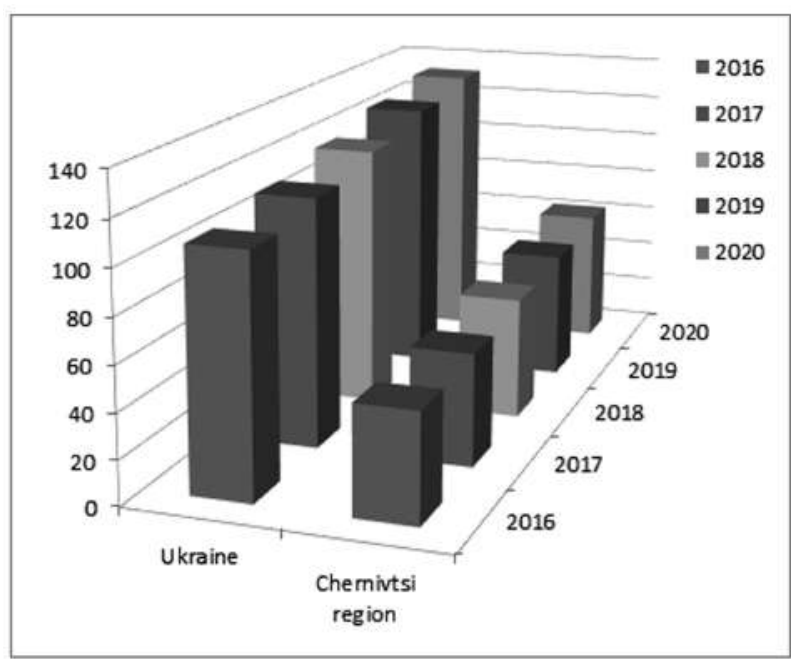

Fig. 5. Dynamics of prevalence of thyroid cancer in Ukraine and Chernivtsi region (per 100 thousand population).

Statistical data concerning dynamics of the primary incidence of thyroid cancer in Ukraine over a five-year period also show an upward trend. In particular, the indicator of the first detected oncopathology in 2015 was $6.9 / 100$ thousand population, reaching a peak in 2019 ( 8.3 / 100 thousand population, an increase of $+20.3 \%)$ and declining slightly by the end of $2020-6.5 / 100$ thousand population (increase $-21.7 \%$ ). The dynamics of the incidence of this pathology among the residents of Chernivtsi region (Fig. 6) was characterized by a wave-like trend with a peak in $2018-4.3 / 100$ thousand population (positive increase in 2015-2018 + 43.3\%; negative - 2018-2020 years $-2.3 \%$ ).

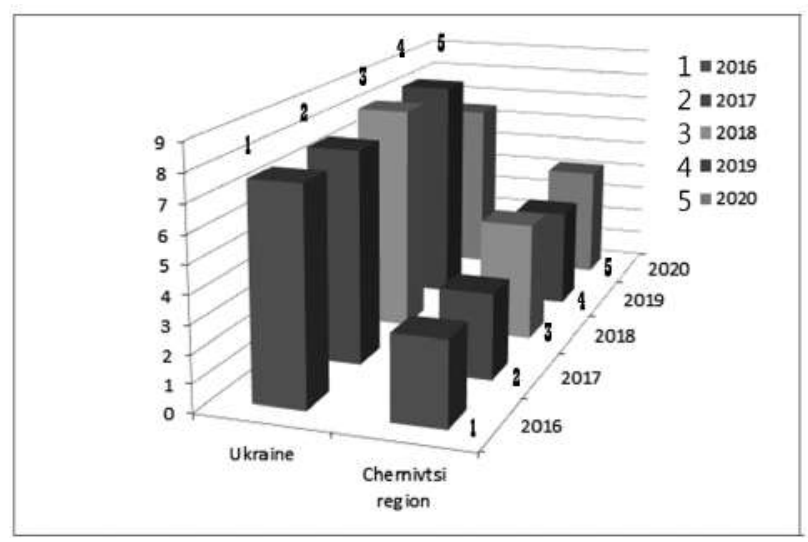

Fig. 6. Dynamics of thyroid cancer incidence in Ukraine and Chernivtsi region (per 100 thousand population).

It is clear that this situation is, on the one hand, a consequence of the influence of well-known risk factors for thyroid cancer, and on the other - may be due to improved early diagnosis, namely an increase in fine needle aspiration biopsy in recent years.

\section{Conclusions}

1.A comparative analysis of the incidence and prevalence of the thyroid diseases among the adult population of Ukraine and Chernivtsi region (per 100 thousand population) during 2015-2020 shows a significant increase in the total number of thyroid pathology in general. Not only the volume has increased, but its structure has also changed (improvement of the diagnosis quality of these pathologies plays an important role). Over the last five years, the level of primary morbidity and prevalence of thyroid nodules in Ukraine has increased, and the situation in Chernivtsi region is slightly better in recent years, which demonstrates the feasibility and effectiveness of the national and regional programs for early detection of pathology.

2.An increase in the primary incidence and prevalence of thyroid cancer in Ukraine and Chernivtsi region during 2015-2019 has been noted, which requires the need for careful diagnosis of thyroid nodules.

3.The incidence of grade I goiter has decreased significantly and there is a slight downward trend in grade II - III goiter in Ukraine as a whole, but the number of newly diagnosed cases in most regions of the western part of Ukraine is higher than the national average.

4.Active identification of persons at risk of thyroid nodules developing, based on the study of family history, iodine deficiency, the relationship with the Chernobyl accident helps to improve the quality of life and efficiency of patients, reduce mortality and disability.

\section{Prospects for further research}

To study the relationship between the prevalence of thyroid disease with iodine deficiency and vitamin D deficiency in the Chernivtsi region. 


\section{Список літератури}

1. Кравченко BI. Йодний дефіцит як причина високої розповсюдженості тиреоїдної патології серед населення регіонів, що постраждали після аварії на ЧАЕС. Журнал Національної академії медичних наук України. 2016;22(2):222-9.

2. Маменко МЄ. Профілактика йододефіцитних захворювань: що має знати та може зробити педіатр і лікар загальної практики? (Клінічні рекомендації). Современная педиатрия. 2017;2:8-6. doi: 10.15574/SP.2017.82.8

3. Паньків ВI. Йодний дефіцит і вагітність: стан проблеми та шляхи іiі вирішення. Медичні аспекти здоров'я жінки. $2008 ; 5: 27-34$.

4. Ткаченко ВI, Максимець ЯА, Видиборець НВ, Коваленко ОФ Аналіз поширеності тиреоїдної патології та захворюваності на неї серед населення Київської області та України за 2007-2017 pр. Міжнародний ендокринологічний журнал. 2018;14(3):272-7. doi: https://doi.org/10.22141/22240721.14 .3 .2018 .136426

5. Скрипник НВ, Марусин ОВ. Динаміка захворюваності й поширеності вузлових утворень щитоподібної залози за десятирічний період (2006-2016 рр.) в Україні та на Прикарпатті. Практикуючий лікар. 2017;6(2):26-9.

6. Taylor PN, Albrecht D, Scholz A, Gutierrez-Buey G, Lazarus JH, Dayan CM, et al. Global epidemiology of hyperthyroidism and hypothyroidism. Nat Rev Endocrinol. 2018;14(5):301-16. doi: 10.1038/nrendo. 2018.18

7. Довідник основних показників діяльності ендокринологічної служби України за 2020 р. Київ: Інститут ендокринології та обміну речовин ім. В.П. Комісаренка; 2021.

8. Boehm BO, Steinert M, Dietrich JW, Peter RU, Belyi D, Wagemaker G, et al. Thyroid examination in highly radiationexposed workers after the Chernobyl accident. Eur J Endocrinol. 2009;160(4):625-30. doi: 10.1530/eje-08-0492

9. Камінський ОВ, Афанасьєв ДЄ, Коваленко ОМ. Стандарти надання допомоги хворим 3 патологічними станами щитоподібної залози в умовах дії негативних чинників довкілля. Київ: Ферзь; 2012. 159 с.

10. Скрипник НВ, Боцюрко ВI, Дідушко ОМ, Костіцька IO, Бабенко ІГ, Вацеба ТС, та ін. Поширеність вузлових захворювань щитоподібної залози в Івано-Франківській області. Здобутки клінічної і експериментальної медицини. 2016;3:139-40.

\section{References}

1. Kravchenko VI. Yodnyi defitsyt yak prychyna vysokoi rozpovsiudzhenosti tyreoidnoi patolohii sered naselennia rehioniv, scho postrazhdaly pislia avarii na ChAES [Iodine deficiency as a cause of high prevalence of thyroid pathology in the population of regions affected by the Chernobyl accident]. Zhurnal Natsional'noi akademii medychnykh nauk Ukrainy. 2016;22(2):222-9. (in Ukrainian).

2. Mamenko MYe. Profilaktyka yododefitsytnykh zakhvoriuvan': scho maie znaty ta mozhe zrobyty pediatr i likar zahal'noi praktyky? (Klinichni rekomendatsii) [Prevention of iodine deficiency disorders: what should know and can do a pediatrician and general practitioner? (Clinical practice guideline)]. Sovremennaya pediatriya. 2017;2:8-6. doi: 10.15574/ SP.2017.82.8 (in Ukrainian).

3. Pan'kiv VI. Yodnyi defitsyt i vahitnist': stan problemy ta shliakhy yii vyrishennia [Iodine deficiency and pregnancy: the state of the problem and ways to solve it]. Medychni aspekty zdorov'ia zhinky. 2008;5:27-34. (in Ukrainian).

4. Tkachenko VI, Maksymets YaA, Vydyborets NV, Kovalenko OF. Analiz poshyrenosti tyreoidnoi patolohii ta zakhvoriuvanosti na nei sered naselennia Kyivs'koi oblasti ta Ukrainy za 20072017 rr. [Analysis of the prevalence and morbidity of thyroid pathology among the populationof Kyiv region and Ukraine for 2007-2017]. International Journal of Endocrinology (Ukraine). 2018;14(3):272-7. doi: https://doi.org/10.22141/22240721.14.3.2018.136426 (in Ukrainian).

5. Skrypnyk NV, Marusyn OV. Dynamika zakhvoriuvanosti y poshyrenosti vuzlovykh utvoren' schytopodibnoi zalozy za desiatyrichnyi period (2006-2016 rr.) v Ukraini ta na Prykarpatti [Dynamics of incidence and prevalence of thyroid gland nodules in ukraine and in the carpathian region for ten years (2006-2016)]. Praktykuiuchyi likar. 2017;6(2):26-9. (in Ukrainian).

6. Taylor PN, Albrecht D, Scholz A, Gutierrez-Buey G, Lazarus JH, Dayan CM, et al. Global epidemiology of hyperthyroidism and hypothyroidism. Nat Rev Endocrinol. 2018;14(5):301-16. doi: 10.1038/nrendo. 2018.18

7. Dovidnyk osnovnykh pokaznykiv diial'nosti endokrynolohichnoi sluzhby Ukrainy za 2020 r. [Handbook of key performance indicators of the endocrinology service of Ukraine for 2020]. Kiev: Instytut endokrynolohii ta obminu rechovyn im. V.P. Komisarenka; 2021. (in Ukrainian).

8. Boehm BO, Steinert M, Dietrich JW, Peter RU, Belyi D, Wagemaker $\mathrm{G}$, et al. Thyroid examination in highly radiationexposed workers after the Chernobyl accident. Eur J Endocrinol. 2009;160(4):625-30. doi: 10.1530/eje-08-0492

9. Kaminsky OV, Afanasyev DE, Kovalenko OM. Standarty nadannia dopomohy khvorym $z$ patolohichnymy stanamy schytopodibnoi zalozy $\mathrm{v}$ umovakh dii nehatyvnykh chynnykiv dovkillia [Standards of care for patients with pathological conditions of the thyroid gland under the influence of negative environmental factors]. Kiev: Ferz'; 2012. 159 p. (in Ukrainian).

10. Skrypnyk NV, Botsiurko VI, Didushko OM, Kostitska IO, Babenko IH, Vatseba TS, ta in. Poshyrenist vuzlovykh zakhvoriuvan shchytopodibnoi zalozy v Ivano-Frankivskii oblasti [Prevalence of nodular thyroid diseases in Ivano-Frankivsk region]. Achievements of clinical and experimental medicine. 2016;3:139-40. (in Ukrainian).

\section{Information about the authors:}

Kamyshna I.I. - MD, PhD, Department of Medical Rehabilitation, I.Horbachevsky Ternopil National Medical University, Ternopil, Ukraine.

Pavlovich LB - MD, PhD, Department of Clinical Immunology, Allergology and Endocrinology, Bukovinian State Medical University, Chernivtsi, Ukraine.

Maslyanko VA - MD, PhD, Department of Clinical Immunology, Allergology and Endocrinology, Bukovinian State Medical University, Chernivtsi, Ukraine.

Chornenka Zh.A. - MD, PhD, Department of Social Medicine and Public Health, Bukovinian State Medical University, Chernivtsi, Ukraine.

\section{Відомості про авторів:}

Камишна I.I. - к.мед.н, доцент кафедри медичної реабілітації, Тернопільський національний медичний ISSN 1727-4338 https://www.bsmu.edu.ua

Клінічна та експериментальна патологія. 2021. Т.20, № 3 (77) 
університет ім. І.Я. Горбачевського, м. Тернопіль, Україна.

Павлович Л.Б. - к.мед.н, доцент кафедри клінічної імунології, алергології та ендокринології, Буковинський державний медичний університет, м. Чернівці, Україна.

Маслянко В.А. - к.мед.н, доцент кафедри клінічної імунології, алергології та ендокринології, Буковинський державний медичний університет, м. Чернівці, Україна.

Чорненька Ж.А. - к.мед.н, доцент кафедри соціальної медицини та організації охорони здоров'я, Буковинський державний медичний університет, м. Чернівці, Україна.

\section{Сведения об авторах:}

Камышная И.И. - к.мед.н, доцент кафедры медицинской реабилитации, Тернопольский национальный медицинский университет им. Горбачевского, г. Тернополь, Украина.

Павлович Л.Б. - к.мед.н, доцент кафедры клинической иммунологии, аллергологии и эндокринологии, Буковинский государственный медицинский университет, г. Черновцы, Украина.

Маслянко В.А. - к.мед.н, доцент кафедры клинической иммунологии, аллергологии и эндокринологии, Буковинский государственный медицинский университет, г. Черновцы, Украина.

Черненькая Ж.А. - к.мед.н, доцент кафедры социальной медицины и организации здравоохранения, Буковинский государственный медицинский университет, г. Черновцы, Украина.

Стаття надійшла до редакиії 14.07.2021 p.

Рецензент - проф. Пашковська Н.В.

(C) I.I. Kamyshna, L.B. Pavlovich, V.A. Maslyanko, Zh.A. Chornenka, 2021

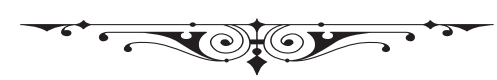

